\title{
INTENSIFIKASI BAHASA ARAB MELALUI “PESANTREN KILAT ALSUN"
}

\author{
Ainun Syarifah \\ Uinversitas Islam Negeri Sunan Ampel Surabaya \\ ainunsyarifah12@gmail.com \\ Chusein Aziz \\ Uinversitas Islam Negeri Sunan Ampel Surabaya \\ chuseinaziz@uinsby.ac.id
}

\begin{abstract}
Arabic Intensive Program is an Arabic learning program that has been implemented by Madrasah Alsun. The program aims to improve the language competence of the Arabic Teacher Education (PBA) Study Program students whose language competence is still below the standard. PBA study program then cooperated with Madrasah Alsun Sidoarjo to hold Arabic Intensive Program through 'Pesantren Kilat' to improve the Arabic language competence for the students. Pesantren Kilat was held during the two-month semester break. This research used descriptive qualitative research with purposive sampling. The data collection techniques in this study include: Observation, Interview, Documentation, Triangulation and Forum Group Discussion (FGD). The data analysis technique is Interactive Analysis model. In this model, there are three components: data reduction, data presentation, and conclusion or verification. According to the results of the interviews conducted by the researcher, it can be concluded that the success of language learning, including the Arabic language, is not solely related to the competence of the teachers, but actually includes all the components such as capacity of the students, the teaching methods, the supporting media, the learning environments and students' motivation. Various methods are often used to achieve the effectiveness of learning in the classroom, especially for the students with low Arabic competence
\end{abstract}

Key word: Arabic language, pesantren kilat, madrasah Alsun

\begin{abstract}
Abstrak: Program intensif bahasa Arab adalah program pembelajaran bahasa Arab yang telah dilaksanakan oleh Madrasah Alsun. Program ini bertujuan untuk meningkatkan kompetensi bahasa siswa Program Studi Pendidikan Bahasa Arab (PBA) yang kompetensi bahasanya masih di bawah standar. Program studi PBA kemudian bekerja sama dengan Madrasah Alsun Sidoarjo untuk menyelenggarakan program intensif bahasa Arab melalui "pesantren kilat" untuk meningkatkan kompetensi bahasa Arab bagi mahasiswa. Pesantren kilat diadakan selama liburan semester selama dua bulan. Penelitian ini menggunakan penelitian deskriptif kualitatif dengan purposive sampling. Teknik pengumpulan data dalam penelitian ini meliputi: observasi, wawancara, dokumentasi, triangulasi dan Forum Diskusi Kelompok (FGD). Teknik analisis data adalah model analisis interaktif. Dalam model ini ada tiga komponen: reduksi data, penyajian data dan kesimpulan atau verifikasi. Menurut hasil wawancara yang dilakukan oleh peneliti dapat disimpulkan bahwa keberhasilan pembelajaran bahasa, termasuk bahasa Arab tidak semata-mata berkaitan dengan kompetensi guru, tetapi sebenarnya mencakup semua komponen seperti kapasitas dari siswa, metode pengajaran, media pendukung, lingkungan belajar dan motivasi siswa. Berbagai metode
\end{abstract}


sering digunakan untuk mencapai efektivitas pembelajaran di kelas, terutama bagi siswa dengan kompetensi bahasa Arab rendah.

Kata kunci: Bahasa Arab, pesantren kilat, madrasah Alsun

\section{PENDAHULUAN}

Kemajuan ilmu pengetahuan ( al-'ulum) dan teknologi ( al-tiqni) di era global ini tidak dapat dibendung, bahkan semakin menggila, dan bahasa menjadi piranti paling penting dalam persaingan di era ini. Seseorang yang tidak memiliki bahasa internasional akan siap tenggelam bahkan tidak akan mampu bersaing dalam kancah global, maka tidak dapat dipungkiri kemampuan berbahasa asing merupakan sebuah pilihan hidup. Bahasa Arab, diantara bahasa internasional yang memainkan peranan urgen di era ini, kita tidak lagi hanya berfikir dan berkutat pada memahami kajian-kajian kitab kuning ( turats), namun kita dapat berkomunikasi aktif dengan dunia luar. Tapi di era ini kita masih sering mendapatkan peserta didik kurang memadai dalam penguasaan bahasa arab, meskipun ada gerakan pengembangan bahasa Arab dan sudah menjadi prioritas di lembaga pendidikan terutama lembaga yang bernuansa Islami ${ }^{1}$.

Bahasa merupakan alat komunikasi dan pendukung dalam pergaulan manusia dalam sehari-hari baik antara individu dengan masyarakat, maupun dengan bangsa tertentu. Adapun bahasa Arab merupakan bahasa yang istimewa di dunia ini seperti yang kita ketahui, bahwasannya bahasa Arab tidak hanya merupakan bahasa peradaban, melainkan juga sebagai bahasa persatuan umat Islam di dunia. Bahasa Arab adalah selain merupakan bahasa Al-qur'an (firman Allah atau kitab pedoman umat Islam) yang memiliki uslub yang bermutu juga memiliki sastra yang sangat mengagungkan manusia dan manusia tidak mampu untuk menandingi. Menurut Abdul Alim Ibrahim $(1978 ; 48)$ "bahwa bahasa Arab merupakan bahasa orang Arab dan sekaligus juga merupakan bahasa Islam" 2

Pembelajaran bahasa Arab di lembaga pendidikan, mulai dari tingkat dasar hingga perguruan tinggi, idealnya memungkinkan para peserta didik menguasai empat keterampilan berbahasa (maharat al-istima', maharat al-kalam,

1M. Abdullah Charis, M. Pd, Cara Mudah Berbicara Bahasa Arab, Sebuah Pendekatan Belajar Dan Pembelajaran komunikatif, (Sidoarjo: CV LISAN ARABI, 2014) hal. 1

${ }^{2}$ Azhar Arsad, Bahasa Arab dan beberapa Metode Pengajarannya,(Pustaka Pelajar, Yogyakarta, 2003), hal.7 
maharat al-qira'ah, dan maharat al-kitabah) secara fungsional dan proporsional. Hal itu dikarenakan bahasa Arab bukan hanya berfungsi pasif, yaitu sebagai media untuk memahami (al-fahm) apa yang didengar, berita, teks, bacaan dan wacana, melainkan juga berfungsi aktif, yaitu sebagai memahamkan (al-ifham) orang lain melalui komunikasi lisan dan tulisan. ${ }^{3}$

Adapun pembelajaran yang efektif adalah suatu upaya mengetahui berhasil tidaknya pelaksanaan pembelajaran bahasa Arab khususnya baik dari segi proses maupun hasil. Maka peran guru tidak cukup sebagai pengajar saja melainkan dituntut juga sebagai pakar bahasa Arab sangat membantu perkembangan pembelajaran bahasa Arab itu sendiri. Upaya yang dapat dilakukan berupa pengadaan pusat latihan, laboratorium bahasa, media-media yang menyajikan bahasa Arab yang praktis dan buku-buku karya ilmiah yan g menyajikan bahasa Arab yang mudah atau gamblang dan metodologis. ${ }^{4}$

Maka untuk mencapai tujuan pembelajaran, pengajar hendaknya pandai-pandai mengelola kelasnya dengan memperhatikan efektifitas dan efisien dari kegiatan belajar mengajar yang telah direncanakan. Untuk tuntutan itu, pengajar harus membantu para pelajar untuk mencapai pembelajaran yang efektif dan efisien.

Prodi Pendidikan Bahasa Arab adalah merupakan salah satu Prodi yang berada di Fakultas Tarbiyah Dan Keguruan UIN Sunan Ampel Surabaya, dan merupakan salah satu prodi terfavorit karena peranannya sangat urgen dalam era globalisasi ini. Prodi PBA ini mempunyai Visi “Menjadi Pusat Pendidikan Bahasa Arab Yang Unggul Dan Kompetitif Bertaraf Internasional " dan Misi Prodi PBA antara lain;1. Menyelenggarakan Pendidikan Bahasa Arab secara profesional, Inovatif Dan Akuntabel; 2. Mengembangkan Penelitian Pendidikan Bahasa Arab Dan Publikasi Ilmiah Yang Kompetitif Dan Inovatif Serta Relevan Dengan Kebutuhan Masyarakat Global; 3. Menyelenggarakan Pengabdian Masyarakat

\footnotetext{
${ }^{3}$ Ali Ahmad Madkur, 2000. Tadris Funun al-Lughah al-Arabiyyah. Kairo: Dar al-Fikr al-Araby ${ }^{4}$ Tayas Yusuf dan Syaiful Anwar. Metodologi Pengajaran dan Bahasa Arab, (Jakarta:Grafindo Persada 1995)
} 
Dalam Memenuhi Kebutuhan Pembelajaran Bahasa Arab Dan Bahasa Arab Terapan. Untuk dapat mencapai visi misi tersebut, Prodi PBA telah mengembangkan kurikulum pendidikannya sesuai standart tujuan yang diinginkan guna menghasilkan kualitas lulusan yang benar-benar sesuai dengan yang telah ditetapkan dan dapat memiliki kemampuan dan ketrampilan di bidang yang dipelajarinya.

Calon mahasiswa dalam memilih program studi yang akan ditekuninya, seyogyanya menyesuaikan dengan basic keilmuan yang telah dia miliki semasa di sekolah menengah ke atas, agar nantinya dapat mempermudahkannya dalam proses belajar dan lebih cepat dalam menguasai materi keilmuannya, sehingga benar-benar menjadi lulusan yang berkualitas dan sangat berkompeten di bidangnya.

Namun realita yang selama ini terjadi pada Prodi Pendidikan Bahasa Arab adalah para mahasiswa dan mahasiswi yang diterima memiliki latar belakang pendidikan yang berbeda-beda, diantaranya ada yang notabenenya alumni pondok atau Madrasah Aliyah yang sudah punya basic ilmu bahasa Arab, namun tidak sedikit pula dari mereka yang lulusan dari sekolah-sekolah umum yang sama sekali tidak dikenalkan dengan ilmu Bahasa Arab sebelumnya. Sehingga ketika mereka mulai dihadapkan dengan kurikulum Bahasa Arab yang mencakup empat Maharah, mereka sama sekali tidak mampu memahami apalagi menguasainya, yang pada ujungnya tidak sedikit dari mereka yang putus asa dengan mencoba mencari cara untuk keluar dari belenggu kesulitan yang mereka hadapi, salah satu alternatif yang mereka pilih adalah dengan berpindah jurusan/ program studi dan ada juga yang pada akhinya berpindah kampus. Alangkah sangat disayangkan kalau sering terjadi demikian.

Prodi Pendidikan Bahasa Arab telah mencoba menela'ah kembali fenomena yang terjadi tersebut, dan berusaha mencari solusi guna membantu para mahasiswa yang kompetensi bahasa Arabnya masih berada dibawah rata-rata, guna mengentaskan mereka dari kealphaan dalam pemahaman maupun penguasaan materi. Prodi PBA telah melakukan Pre test terkait kompetensi dasar kebahasaan terhadap semua Mahasiswa baru, dan dari hasil pre test tersebut, Prodi PBA memilah antara mahasiswa yang lulus dan yang tidak lulus tes. Dan 
bagi yang tidak lulus tes, prodi PBA menjembatani mereka dengan melakukan kerjasama dengan Madrasah Alsun Sidoarjo guna mengadakan Intensifikasi Bahasa Arab melalui' Pesantren Kilat" untuk membantu meningkatkan kompetensi bahasa Arab bagi para Mahasiswa tersebut. Pesantren kilat tersebut dilaksanakan selama masa liburan semester selama dua bulan. Rumusan masalah pada penelitian ini adalah : Bagaimanakah Efektifitas Intensifikasi Bahasa Arab melalui “Pesantren Kilat Alsun” bagi Mahasiswa Prodi Pendidikan Bahasa Arab Fakultas Tarbiyah Dan Keguruan. penelitian ini bertujuan untuk mengetahui efektifitas Intensifikasi Bahasa Arab melalui " Pesantren Kilat Alsun” terhadap peningkatan kompetensi Bahasa Arab Mahasiswa Prodi Pendidikan Bahasa Arab.

\section{METODE PENELITIAN}

Jenis penelitian yang digunakan dalam penelitian ini adalah jenis penelitian deskriptif kualitatif. Jenis survei deskriptif digunakan untuk menggambarkan populasi yang sedang diteliti. Fokus riset ini adalah perilaku yang sedang terjadi dan terdiri dari data variabel.metodologi kualitatif sebagai prosedur penelitian yang menghasilkan data deskriptif berupa kata-kata tertulis atau lisan atau dari bentuk tindakan kebijakan. ${ }^{5}$ Dengan metode ini peneliti dapat mengumpulkan data - data yang diperlukan. Penyebaran ini akan dilakukan pada mahasiswa Prodi PBA yang sedang mengikuti Intensifikasi Bahasa Arab melalui " Pesantren Kilat", untuk mengetahui efektifitasnya dalam meningkatkan kompetensi bahasa Arab mahasiswa Prodi Pendidikan Bahasa Arab.

Populasi penelitian ini merupakan keseluruhan (universum) dari objek penelitian yang dapat berupa manusia, hewan, tumbuhan, udara, gejala, nilai, peristiwa, sikap hidup, dan sebagainya objek - objek ini dapat menjadi sumber data penelitian ${ }^{6}$.Adapun populasi pada penelitian ini adalah seluruh mahasiswa Prodi Pendidikan Bahasa Arab Fakultas Tarbiyah Dan Keguruan semester II dengan jumlah mahasiswa keseluruhan 90 mahasiswa, jadi populasi dalam penelitian ini berjumlah 90 mahasiswa. Berdasarkan jumlah dan sifat populasi 
dalam penelitian ini ukuran sampel yang akan di ambil dalam penelitian ini yaitu Purposive sampling juga disebut judgmental sampling, yaitu pengambilan sampel berdasarkan "penilaian" (judgment) peneliti mengenai siapa-siapa saja yang pantas (memenuhi persyaratan) untuk dijadikan sampel. Oleh karenanya agar tidak sangat subjektif, peneliti harus punya latar belakang pengetahuan tertentu mengenai sampel dimaksud (tentu juga populasinya) agar benar-benar bisa mendapatkan sampel yang sesuai dengan persyaratan atau tujuan penelitian (memperoleh data yang akurat). Adapun Sampel yang diambil peneliti adalah sejumlah 35 mahasiswa, karena mereka adalah mahasiswa yang tidak lulus dalam placement Test dan yang akan diikutkan pada Intensifikasi Bahasa Arab melalui “ Pesantren Kilat Alsun”.

Untuk mendapatkan beberapa jenis data dari sumber data, maka dalam penelitian ini diperlukan adanya teknik pengumpulan data, antara lain:

1. Observasi yaitu pengamatan dan pencatatan sistematis terhadap fenomena-fenomena yang diteliti.7.Pada penelitian ini yang menjadi sasarannya adalah bagaimana efektifitas Intensifikasi Bahasa Arab melalui "pesantren kilat Alsun" dalam meningkatkan kompetensi Bahasa Arab Mahasiswa Prodi Pendidikan Bahasa Arab di fakultas Tarbiyah Dan Keguruan UIN Sunan Ampel Surabaya

2. Wawancara (interview), Dalam wawancara ini sasarannya adalah Instruktur bahasa Arab Madrasah Alsun dan Mahasiswa, wawancara ini digunakan untuk menggali data tentang bagaimana efektifitas Intensifikasi Bahasa Arab melalui "pesantren kilat Alsun" bagi Mahasiswa Prodi Pendidikan Bahasa Arab di fakultas Tarbiyah Dan Keguruan UIN Sunan Ampel Surabaya

3. Dokumentasi yaitu pencarian data mengenai hal-hal atau variabel yang berupa catatan, transkrip, prasasti, buku, surat, majalah, notulen, agenda, dan sebagainya. ${ }^{8}$ Adapun dokumentasi yang diperlukan dalam penelitian ini adalah jurnal perkuliahan, absensi, nilai, buku materi, dan dokumen-

\footnotetext{
7 Sutrisno Hadi, Metodologi Research (Yogyakarta: Andi Offset, 1991), 136.

${ }^{8}$ Arikunto, Prosedur Penelitian, 200.
} 
dokumen yang berisi informasi tentang lembaga dan yang berkaitan dengan penelitian.

4. Triangulasi Yaitu teknik pemeriksaan keabsahan data yang memanfaatkan sesuatu yang lain dalam membandingkan hasil wawancara terhadap objek penelitian ${ }^{9}$. Triangulasi dapat dilakukan dengan menggunakan teknik yang berbeda yaitu wawancara, observasi dan dokumentasi. Adapun untuk mencapai kepercayaan itu, maka ditempuh langkah sebagai berikut:

a. Membandingkan data hasil pengamatan dengan data hasil wawancara

b. Membandingkan apa yang dikatakan orang di depan umum dengan apa yang dikatakan secara pribadi.

c. Membandingkan hasil wawancara dengan isi suatu dokumen yang berkaitan.

1. FGD Group Discussion adalah suatu proses diskusi yang melibatkan para pakar (ahli) untuk mengidentifikasi masalah, analisis penyebab masalah, menentukan cara-cara penyelesaian masalah, dan mengusulkan berbagai alternatif pemecahan masalah dengan mempertimbangkan sumber daya yang tersedia. Dalam diskusi kelompok terjadi curah pendapat (brain storming) di antara para ahli dalam perancangan model atau produk.Mereka mengutarakan pendapatnya sesuai dengan bidang keahlian masing-masing. ${ }^{10}$

Teknik ini digunakan untuk mengungkap permaknaan dari suatu kelompok berdasarkan hasil diskusi yang terpusat pada suatu permasalahan tertentu. FGD juga dimaksudkan untuk menghindari permaknaan yang salah dari seorang peneliti terhadap focus masalah yang sedang diteliti. ${ }^{11}$ Teknik ini di gunakan sebagai bahan masukan untuk merevisi atau penyempurnaan produk baik produk terbatas, luas dan terakhir. Jadi penulis melakukan analisis masalah dengan berdiskusi bersama para pakar atau ahli di bidang pembelajaran Bahasa Arab .

${ }^{9}$ Moeleong, Metode Penelitian Kualitatif, 300.

${ }^{10}$ Ibid., 20.

11. H.B. Sutopo,Metodologi Penelitian Kualitatif(Surakarta : UNS Press, 2002).73 
Sebenarnya ada beragam tahapan dalam teknik analisis data ini, seperti yang ditawarkan oleh Lexy J. Moleong, yaitu dengan menelaah seluruh data yang tersedia dari berbagai sumber. Setelah dibaca, dipelajari dan ditelaah lalu mengadakan reduksi, penyajian dan penarikan simpulan. ${ }^{12}$

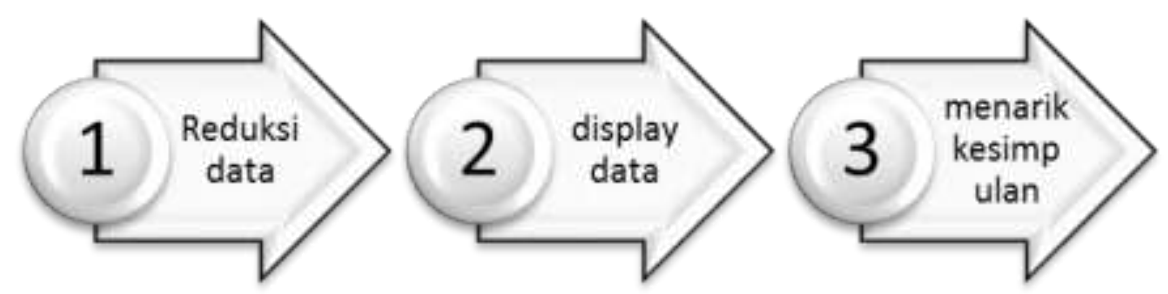

\section{Teknik Analisa Data Penelitian Moleong}

Tak jauh dari Moleong, Sanaky juga merumuskan analisis data sebagai suatu rangkaian kegiatan yang dimulai dari reduksi data, display data, pemahaman/interpretasi/penafsiran, serta yang terakhir adalah mengambil kesimpulan. ${ }^{13}$

Dalam penelitian ini, teknik analisis yang digunakan adalah model Analisis Interaktif. Di dalam model ini terdapat tiga komponen yang terdiri dari reduksi data, sajian data, dan penarikan kesimpulan atau verifikasi. ${ }^{14}$ Aktivitasnya berbentuk interaksi ketiga komponen analisis secara sistematik sebagai berikut:

1. Reduksi Data (Data Reduction) Reduksi data merupakan cara yang dilakukan peneliti dalam melakukan analisis untuk mempertegas, memperpendek, membuat fokus, membuang hal-hal yang tidak penting dan mengatur data sedemikian rupa sehingga dapat menarik kesimpulan atau memperoleh pokok temuan. Proses berlangsung hingga laporan akhir selesai atau dengan kata lain bahwa data adalah proses seleksi, penafsiran, penyederhanaan dan abstraksi data kasar.

2. Sajian Data (Data Display) Supaya mendapat gambaran yang jelas tentang data keseluruhan, yang pada akhirnya akan dapat menyusun kesimpulan,

\footnotetext{
12. Tentang analisis data kualitatif ini baca selengkapnya dalam Lexy J. Moleong, Metodologi Penelitian Kualitatif (Bandung; PT Remaja Rosdakarya, 2001), 247.

13. Sanaky, Pengolahan dan Analisis Data, dalam http//: www.sanaky.com/ Materi IX.

14 . Sugiyono. 2011. Metode Penelitian Pendidikan: Pendekatan Kuantitatif, Kualitatif, dan R\&D. Bandung: Alfabeta.245-252
} 
maka peneliti berusaha menyusunnya ke dalam penyajian data dengan baik dan jelas agar dapat dimengerti dan dipahami.

3. Penarikan Kesimpulan (Conclusion Drawing) Dalam penelitian ini seleksi data, penarikan kesimpulan sudah dimulai dari proses awal diperolehnya data. Kesimpulan dalam penelitian ini adalah merupakan temuan baru yang sebelumnya belum pernah ada. Temuan dapat berupa deskripsi atau gambaran suatu obyek yang sebelumnya masih remang-remang atau gelap sehingga setelah diteliti menjadi jelas, dapat berupa hubungan kausal atau interaktif, hipotesis atau teori.

\section{PENYAJIAN DATA}

\section{Pesantren Kilat “Alsun”}

Istilah pesantren kilat mengandung dua kata yaitu pesantren dan kilat. Dalam Kamus Besar Bahasa Indonesia "Pesantren berarti asrama tempat santri atau tempat murid-murid belajar mengaji;pondok"

Pesantren adalah suatu lembaga pendidikan agama Islam yang didalamnya terdapat seorang kiyai (pendidik) yang tugasnya mendidik dan mengajar para santri (siswa) yang bertempat tinggal (mondok/menginap) dengan menggunakan asrama (pondokan) untuk tinggal dan masjid untuk ibadah dan mengaji (belajar). Sedangkan kilat maksudnya karena para santri mondok (belajar) dalam waktu yang singkat.

Dengan demikian pesantren kilat merupakan kegiatan yang dilakukan oleh lembaga dalam bidang pendidikan tertentu untuk memperdalam pemahaman terhadap bidang tersebut, yang dilaksanakan pada waktu tertentu. Pesantrean Kilat "Alsun” adalah Program pembinaan Kebahasaan yang telah dilaksanakan oleh Madrasatul Alsun yang bertujuan untuk membantu Mahasiswa Mahasiswi Program Pendidikan Bahasa Arab dalam meningkatkan kemampuan kebahasaannya.

Pesantren Kilat ini dilaksanakan dalam satu semester sekali, bertepatan dengan liburan semester Fakultas Tarbiyah Dan Keguruan UIN Sunan Ampel Surabaya. 
Pesantren Kilat ini dilaksanakan atas dasar kerjasama antara Prodi Pendidikan Bahasa Arab Fakultas Tarbiyah Dan Keguruan dengan Madrasatul Alsun Sidoarjo yang saat ini dibina langsung oleh Direktur Madrasatul alsun yaitu Ustadz Nasaruddin, Dip. Tal.

Kerjasama ini dilakukan dengan tujuan untuk membantu para Mahasiswa dalam meningkatkan kompetensinya dalam bidang Bahasa Arab yang selama ini masih dianggap sangat kurang.

\section{Intensifikasi Bahasa Arab Melalui Pesantren Kilat “Alsun”}

Program Intesifikasi Bahasa Arab melalui Pesantren Kilat “ Alsun” adalah Suatu Program pembinaan kebahasaan secara intensif yang telah dilaksanakan oleh Madrasatul Alsun Sidoarjo dibawah bimbingan Ustadz Nasir Abdur Rahman, Dip. Tal . Beliau secara langsung membimbing para Mahasiswa prodi Pendidikan Bahasa Arab untuk meningkatkan Maharah Lughowiyah mereka, yang selama ini dianggap masih dibawah standar.Program Intensifikasi Bahasa Arab ini dilaksanakan tiga kali dalam seminggu dalam durasi waktu dua jam setengah.Adapun materi yang diberikan adalah mencakup empat kompetensi bahasa yaitu Maharah Istima', Maharah Kalam, Maharah Qiro'ah dan Maharah Kitabah.

\section{Target dan Tujuan Intensifikasi Bahasa Arab}

Sebagaimana target dan tujuan pembelajaran bahasa secara umum, Intensifikasi Bahasa Arab melalui Pesantren Kilat “Alsun" sengaja diselenggarakan dengan tujuan agar dapat membantu mahasiswa peserta program ini dapat memiliki kemampuan dan keterampilan bahasa Arab secara aktif meliputi seluruh kompetensi kebahasaan, yaitu istima' (pendengaran), kalâm (berbicara), qirâ'ah (membaca), dan kitâbah (menulis) dengan baik dan benar. Berpijak pada logika berpikir demikian, maka segala bentuk aktivitas dan regulasi yang diberlakukan di dalamnya harus mengarah pada pencapaian tujuan tersebut.

\section{ANALISIS DATA}


Setelah pemaparan data di atas, bagian analisis data ini hendak memaparkan beberapa temuan penting yang disarikan dari penelusuran melalui wawancara dan observasi partispatif terhadap para instruktur dan Mahasiswa program Intensifikasi Bahasa Arab melalui pesantren Kilat Alsun.

Dari beberapa wawancara yang dilakukan peneliti, dapat ditarik benang merah bahwa keberhasilan pembelajaran bahasa, termasuk di dalamnya bahasa Arab, tidak melulu ditanggungkan kepada kompetensi para pengajar, tapi sesungguhnya mencakup seluruh komponen yang meliputi kapasitas peserta didik, metode yang digunakan, media penunjang, dan kondisi lingkungan pembelajaran serta Motivasi yang dimiliki oleh peserta didik itu sendiri. Tentu saja, peran pengajar memang signifikan, tapi tidak dapat dipungkiri pula bahwa sistem yang dibangun, terutama oleh pemangku kebijakan, juga turut andil dalam suksesi pembelajaran bahasa.

Dalam konteks Intensifikasi bahasa Arab di Madrasah Alsun, terdapat beberapa kegiatan yang dilakukan para instruktur untuk menunjang keberhasilan pembelajaran para mahasiswa, yaitu konsorsium dua mingguan yang dihelat untuk mengevaluasi pembelajaran, sharing metode dan strategi yang diterapkan masing-masing instruktur di kelas, dan problem-problem yang dihadapi.

Muhammad Budiono, salah seorang instruktur, menandaskan bahwa untuk mencapai efektifitas pembelajaran di kelas, ia seringkali menerapkan berbagai metode dan strategi, sesuai dengan topik pembelajaran, terutama pada Mahasiswa yang memang kapasitasnya sangat rendah dibidang Bahasa Arab. Secara teoritis dan praktis, penggunaan metode eklektik memang lebih pas untuk kondisi mahasiswa yang beragam, terlebih pada program yang alokasi waktunya dibatasi. ,Dan itu sesungguhnya kelemahan mendasar yang dialami di Program Intensisfikasi Bahasa Arab ini, , tambahnya. Artinya, alokasi waktu yang sangat minim, ditambah beragamnya latar belakang dan kemampuan mahasiswa, menuntut para instruktur untuk senantiasa aktif dalam mencari terobosanterobosan metode dan strategi yang pas untuk mereka, sebab belum ada lingkungan bahasa yang tercipta. Karena tidak ada lingkungan bahasa, yang alami, seperti di pesantren atau yang di asrama, maka satu-satunya tempat untuk 
berlatih itu ada dalam kelas. Sehingga belajarnya minim. Sedangkan bahasa itu filosofisnya antara lain adalah habit, kebiasaan. Bahasa itu kebiasaan. Oleh karena kebiasaan, maka bahasa itu butuh dipraktikkan. Satu-satunya tempat untuk mempraktikkan ada dalam kelas.

Minimnya ,jam terbang' mahasiswa dalam praktik berbahasa Arab, secara sadar diakui oleh Direktur Madrasah Alsun ini, yakni Drs. Nasir Abdurrahman Dip.Tal. ,Itu mengapa yang terpenting dari proses pembelajaran Bahasa Arab ini bukan dari buku materi yang diajarkan tapi lebih pada metodenya, cara penyajiannya. Dan itu yang sering disampaikan oleh Ustadz Nasir dalam rapat evaluasi dengan para Instrukturnya, instruktur dituntut untuk ,bicara' secara proporsional. Dalam pembelajaran bahasa, idealnya adalah memberikan peluang seluas-luasnya kepada peserta untuk praktik dan interaktif satu sama lain. Singkatnya, buku itu hanya sebagai stimulus dan sentra atau poros pembicaraan yang harus didiskusikan oleh para peserta.

Maka, kalau bahasa diajarkan melalui pendekatan keterampilan, keterampilannya ada empat: mendengar, berbicara, membaca dan menulis. Tetapi keterampian berbicara ini harus dominan dan mengatasi semuanya. Harus meliputi semua kegiatan pembelajaran dalam kelas. Artinya, sekalipun keterampilan itu membaca, tetapi nanti dililit dengan berbicara. Topik bahasannya berupa keterampilan menulis, misalnya, maka sebelumnya harus didiskusikan dulu teksnya yang akan ditulis. Berbicara pun begitu. Mereka mendengarkan telling story lebih dulu, cerita pendek, kemudian cerita itu yang didiskusikan. Dan Instruktur harus banyak diam, hanya sekedar memberikan stimulus, yang kemudian harus dilakukan oleh peserta. Peserta itulah yang harus melakukan kegiatan berbahasa, baik mendengar, berbicara, membaca dan menulis. Bukan instrukturnya. Instruktur hanya sebagai fasilitator.

Dalam Program Intensifikasi Bahasa Arab ini, para Instruktur selalu memberi motivasi kepada Mahasiswa untuk berani berbicara dengan menggunakan Bahasa Arab dan tidak perlu takut salah. Belajar Bahasa adalah belajar berkomunikasi dengan menggunakan bahasa tersebut,.Dorongan inilah yang bisa membuat semua Mahasiswa termotivasi untuk lebih berani berbicara menggunakan Bahasa Arab tanpa dihantui dengan rasa takut akan salah dalam 
pengucapannya. Keberhasilan program Intensifikasi Bahasa Arab ini terlihat dari perubahan yang terjadi secara signifikan terhadap performen dan kompetensi Mahasiswa, yakni yang awalnya mereka takut dan malu ketika didorong untuk berbicara dengan Bahasa Arab, namun sekarang sangat terlihat keberanian mereka untuk berkomunikasi dengan menggunakan Bahasa Arab ketika di dalam kelas, dan dampak itulah yang dapat meningkatkan kompetensi kebahasaan mereka di bidang Bahasa Arab, sehingga setelah mengikuti program Intensifikasi Bahasa Arab ini, mereka lebih percaya diri dan lebih bisa mengikuti perkuliahan yang dilaksanakan di Prodi Pendidikan Bahasa Arab. Dan bukti Kelulusan mereka dalam mengikuti Program Intensifikasi Bahasa Arab ini adalah dengan mendapatkan sertifikat kelulusan dari Madrasah Alsun.

\section{DAFTAR PUSTAKA}

Arikunto, S. "Prosedur Penelitian Suatu Pendekatan Praktis". Rineka Cipta, Bandung, 2002.

Arsad, Azhar. Bahasa Arab dan beberapa Metode Pengajarannya. Pustaka Pelajar, Yogyakarta, 2003.

Charis, M. Abdullah. Cara Mudah Berbicara Bahasa Arab, Sebuah Pendekatan Belajar Dan Pembelajaran komunikatif. Sidoarjo: CV LISAN ARABI, 2014.

Hadi,Sutrisno."Metodologi Research".Yogyakarta: Andi Offset, 1991.

Madkur, Ali A. 2000. Tadrîs Funûn al-Lughah al-Arabiyyah. Kairo: Dar al-Fikr alAraby.

Moeleong, Lexy. 2002. "Metode Penelitian Kualitatif”. Bandung: Remaja Rosdakarya.2001.

Sanaky, "Pengolahan dan Analisis Data", dalam http//: www.sanaky.com/ Materi IX.

Sugiyono. Metode Penelitian Pendidikan: Pendekatan Kuantitatif, Kualitatif, dan R\&D. Bandung: Alfabeta, 2011.

Sutopo,H.B."Metodologi Penelitian Kualitatif. Surakarta" : UNS Press, 2002. 
Sugiyono. Metode Penelitian Pendidikan: Pendekatan Kuantitatif, Kualitatif, dan R\&D. Bandung: Alfabeta, 2011.

Yusuf, Tayas dan Syaiful Anwar."Metodologi Pengajaran dan Bahasa Arab". Jakarta:Grafindo Persada, 1995. 